DEPAITAMENTO DE ANATOMIA PATOLÓGICA

Diretor: Prof. Dr. Euclydes O. Martins

DEPARTAMENTO DE ZOOTECNIA

Diretor: Prof. 1)r. João Soares Veiga

MONSTROS ANIDIANOS EM BOVINOS (*)

(ANIDIAN MONSTERS IN BOVINES)

AJAYR M. SALIBA

NOE MASOTTI

Assistente

Assistente

Segundo a classificação teratológica de Saint Hilaire (cit. PETIT $^{3}$ ), anidianos são monstros pertencentes à ordem dos onfalositas, definidos como sendo aquêles que não possuem coração, ou o possuem rudimentar. A nutrição faz-se pela conexão com o cordão umbelical ou placenta de um irmão gêmeo, bem formado.

Os onfalositas dividem-se em:

a) Acefalianos - sem cabeça reconhecivel, revelando vestígios à análise anatômica; às vêzes destacam-se um ou dois membros.

b) Paracefalianos (para = quase, ao lado) quando a cabeça é imperfeita, mas, reconhecível. São observados, ainda, vestígios des órgãos dos sentidos.

c) Anidianos (eidos = forma) - são massas globosas ou ovóides, revestidas de pele e pêlos, contendo no seu interior tecido conjuntivo, serosidade e tecido adiposo. Salienta-se no mesmo um cordão umbelical.

d) Acormianos (kormos $=$ tronco) - quando se reconhece nos mesmos apenas a cabeça e a extremidade pelvi-coccigeana.

Lavocat (cit. GUINARD ${ }^{2}$ ) estudou, em 1866, um feto anidiano bovino, que apresentava bôca rudimentar imperfurada, língua imperfeitamente desenvolvida, dentes incisivos implantados nos alvéolos do maxilar inferior, e no interior da massa, sete pequenos ossos.

BLANC ${ }^{1}$ descreveu os anidianos como sendo monstros que não possuem características da sua espécie, sendo formados por um revestimento cutâneo, recoberto de pêlos, presos por um cordão

(*) Apresentado a XI Reunião Anual da Sociedade Paulista de Medicina Veterinária, em 12 de setembro de 1956. 
umbelical. Internamente podem ser encontrados ossos, substância adiposa, às vêzes, rudimento de alça intestinal e dois ou três vasos.

PETIT $^{3}$ estudando os monstros anidianos, descreveu três casos, sendo um, aquêle citado por Lavocat. O primeiro dêles, proveniente de uma vaca necropsiada com diagnóstico de hidropsia do âmnios, era piriforme, media $25 \mathrm{~cm}$ de comprimento, pesava 1.300 gramas, era recoberto de pele e pêlos, e no interior havia tecido embrionário e adiposo. O segundo pesava $400 \mathrm{~g}$, era recoberto de pele e pêlos, com uma depressão na superfície que seria a bôca; no seu interior foi encontrado o tubo intestinal que, dissecado, apresentava 1 metro de comprimento; notava-se, ainda, resquício de fígado, e estômago rudimentar sob a forma de dois reservatórios independentes um do outro e do tubo digestivo; em tôda a massa foi observada ramificaçāo da veia umbelical.

GUINARD ${ }^{2}$, LESBRE * GARCIA e ALVAREZ ${ }^{5}$ afirmaram que os anidianos são constituídos de massa globosa ou ovóide, revestida de pele e pêlos, possuindo tecido conjuntivo e adiposo, serosidade e alguns ramos de vasos umbelicais.

Certo autor ${ }^{\circ}$ descreveu os anidianos como massas carnosas e volumosas, formadas por um embrião anormal, cujos envoltórios fetais continuaram a realizar suas funçōes e a nutrir seu crescimento.

Entre os animais domésticos, a freqüência é maior na espécie bovina, de acôrdo com os diversos autores.

Darest (cit. PETIT ${ }^{3}$ ) explicou a origem dos monstros, dizendo que dois embriōes diferentes se desenvolvem simultâneamente, derivando de um blastoderma primordialmente único. Durante o desenvolvimento fetal, um dêles paralisa seu desenvolvimento antes da formação do coração, continuando a ser alimentado graças às conexões vasculares que o unem ao seu irmão gêmeo bem conformado.

Para demonstrar a possivel origem dos gêmeos, LESBOUYRIES e DRIEUX ' informaram que nas fêmeas consideradas uniparas, os gêmeos se formam dentro das seguintes possibilidades:
a) ruptura simultânea de uma vesícula em cada ovário;
b) ruptura de duas vesículas num dos ovários;
c) ruptura de uma vesícula contendo dois óvulos;
d) de um óvulo contendo 2 vesículas germinativas;
e) da divisão anormal de um só ôvo. 


\section{OBSERVAÇÓES PESSOAIS}

Os casos aqui descritos estão registrados no Departamento de Anatomia Patológica da Faculdade de Medicina Veterinária da Universidade de São Paulo, sob os números 4801 e 4716 .

Caso I - A formação em questão foi eliminada após o parto normal de uma vaca inseminada artificialmente com sêmen de touro holandês (variedade preta e branca, puro de origem, pertencente ao Pôsto de Inseminação Artificial da Faculdade de Medicina Veterinária da U.S.P.), decorrido período de gestação de 276 dias. O gêmeo era do sexo feminino, de boa constituição, pesava aproximadamente 38 quilos e possuía pelagem característica da raça.

Exame macroscópico - A formação, mais ou menos ovóide, medindo $16 \mathrm{~cm} \times 13 \mathrm{~cm} \times 6 \mathrm{~cm}$, pesava $970 \mathrm{~g}$, e mostrava-se recoberta de pele e pêlos, sendo êstes de côr preta e branca, bem inseridos, lisos, médios e brilhantes. Apresentava cordāo umbelical bem constituído. Em sua superfície existia uma área depilada com, aproximadamente, $3 \mathrm{~cm}$ de diâmetro, mais ou menos profunda, que dava idéia do esbôço do orifício anal. Junto à referida área observava-se formação mamilar com cêrca de $2 \mathrm{~cm}$ de comprimento. A pele era rósea, pigmentada e pouco espêssa. Ao corte notouse saida de regular quantidade de serosidade. Quase tôda a formação revelava-se constituida de tecido conjuntivo, rico em vasos. No centro havia três nódulos com diâmetro por volta de $2 \mathrm{~cm}$, de coloração acastanhada, cuja estrutura lembrava bem a de um gânglio linfático. Patenteou-se, ainda, grande quantidade de tecido adiposo.

Exame microscópico - Foram cortados fragmentos dêsse monstro, fixados em formol a $10 \%$, incluidos em parafina e tratados pelos seguintes métodos: hematoxilina e eosina, Van Gieson, FootWilder. O exame histológico revelou uma formação revestida por epitélio pavimentoso estratificado, bastante queratinizado em alguns pontos e pouco, em outros. No derma, foram observados inúmeros folículos pilosos e não se encontraram glândulas sebáceas ou sudoríparas. Constatou-se grande quantidade de tecido conjuntivo, rico em vasos dilatados e cheios de sangue, alguns com aspecto bastante jovem. Havia, ainda, formação linfóide composta de lóbulos separados entre si por feixes de tecido conjuntivo. Os citados lóbulos, constituídos por linfoblastos e linfócitos continham intenso infiltrado easinofílico. 
Os métodos argênticos demonstraram um retículo bastante delicado.

Registrou-se ausência de estruturas ósseas, rudimentos de aparelho digestivo e anexos.

Caso II - Material teratológico eliminado após o parto normal de um animal da espécie bovina. Não se obteve informação sôbre o sexo do gêmeo.

Exame macroscópico - A formação, mais ou menos ovóide, medindo $12 \mathrm{~cm} \times 8 \mathrm{~cm} \times 5 \mathrm{~cm}$, pesava $320 \mathrm{~g}$. Num dos pontos da menc'onada massa, tinha origem um cordão umbelical bem constituído. A pele era pigmentada e pouco espêssa. Apresentava pêlos de ccloração negra, bem inseridos, lisos, e de médio comprimento. Num dos bordos da referida formação via-se uma área depilada, onde foram encontrados dois cistos, com $2 \mathrm{~cm}$ de diâmetro, contendo, internamente, substância de aspecto gelatinoso, esbôço, taivez da cavidade bucal. Ao corte verificou-se saída de regular quantidade de serosidade. Quase tôda a formação era composta de tecidos conjuntivo, adiposo, e de vasos. Observou-se, também, no seu inter:or, pequena formação cartilaginosa.

Exame microscópico - Este material foi tratado em condições idênticas às do caso anteriormente descrito. O exame microscópico revelou-nos ser a formação revestida por um epitélio pavimentoso estratificado queratinizado. No derma notou-se inúmeros folículos pilosos e não fcram vistas glândulas sebáceas nem sudoríparas. Quase todo o derma apresentava o tecido colagenio dissociado por abudantes hemorragias, constituindo, às vêzes', extensos hematomas. Grande parte da massa era formada por tecido conjuntivo rico em vasos dilatados e cheios de sangue. Lóbulos de tecido adiposo também foram cbservados.

\section{SUMARIO}

Os autores estudaram dois casos de monstros anidianos expulsos após parto normal de duas fêmeas da raça holandesa, variedade preta e branca.

Macroscòpicamente, êsses monstros eram caracterizados por formações ovóides, recobertas de pele e pêlos, pesando 970 e 320 gramas. Verificaram, ainda, que ambas as formaçōes eram con stítuídas de tecido conjuntivo, rico em vasos, e de tecido adiposo. 
Cortes histológicos foram, igualmente, executados para estudar a natureza dos tecidos encontrados.

Face à pesquisa bibliográfica compulsada, adiantam, ainda, serem os primeiros casos descritos na literatura veterinária no Brasil.

\section{SUMMARY}

The authors studied two cases of anidian monsters eliminated after calving of two females of Holstein Frisian breed variety black and white.

By gross examination, the monsters were characterized by ovoid structure, covered with skin and hair weighing 970 and 320 grammes.

They verified also that both of the structure were made by connective tissue rich in vessels and fat tissue as well.

Histological sections were carried out in order to study the different tissue found.

The authors believe after looking over the literature that these monsters were the first cases found in the veterinary literature in Brazil.

\section{BIBLIOGRAFIA}

1) BLANC, L. -. $18^{n}:$ - Les anomalies ohez l'homme et les mammifères. I'aris, J. B. Baillière et Fils

2) GUIN.1?n, 1.. - 1893 -- Précis de téralologic. Anomalies et monstruositis chex l'honme el che\% les animaux. Paris, J. B. Baillière ci liils

3) IE"TIT, (3. - 18:;6 - Contribution à l'élude des monstres anidiens. Rec. Héri. Vél., Paris, 3 (17) : 548-51

4) I.SSBI3L, F. K. - 1927 - Traité de tératologie de l'homme et des animalux domestiques. Parjs, Vigot frères

5) GAIRCIA, I. (i. e ILYARES, R. G. - 1929 - Elementos de teratologia dei hombre y de los animales donésticos. Zaragoza, Tip. "La Acelémica"

(6) _- - 1943 - Moles-Anidean monsters. Canadian Jour. Comp. Moci., 7 (9) : 262-3

7) LESBIYYlit:S, f et DRIEUX, H. - 1952 - Free-martinisme. Rec. Mrd. V'cl. d'Alforl, 128 (12): 737-52 



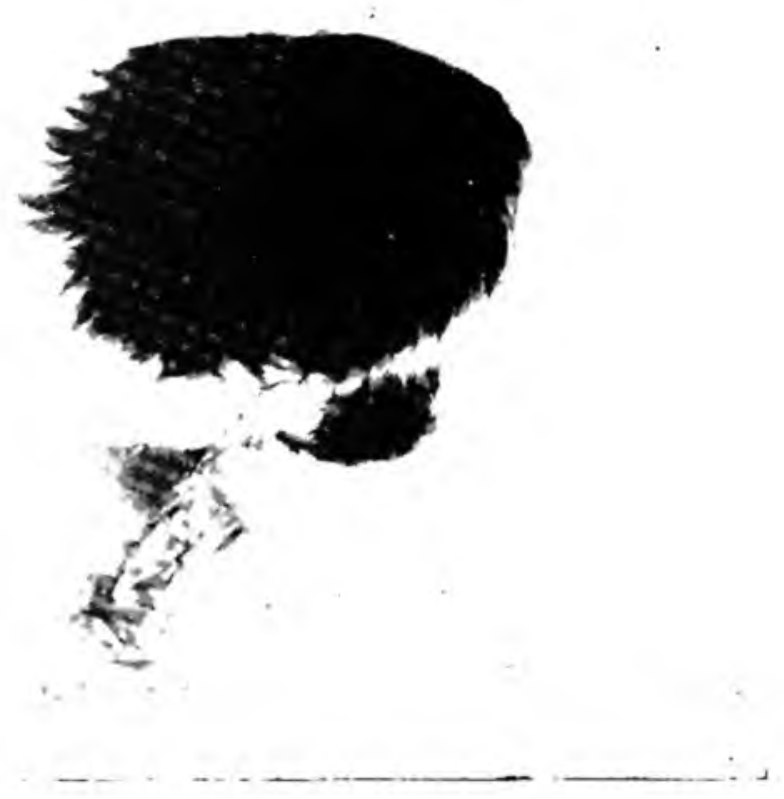

Caso I - Monstro Anidiano 


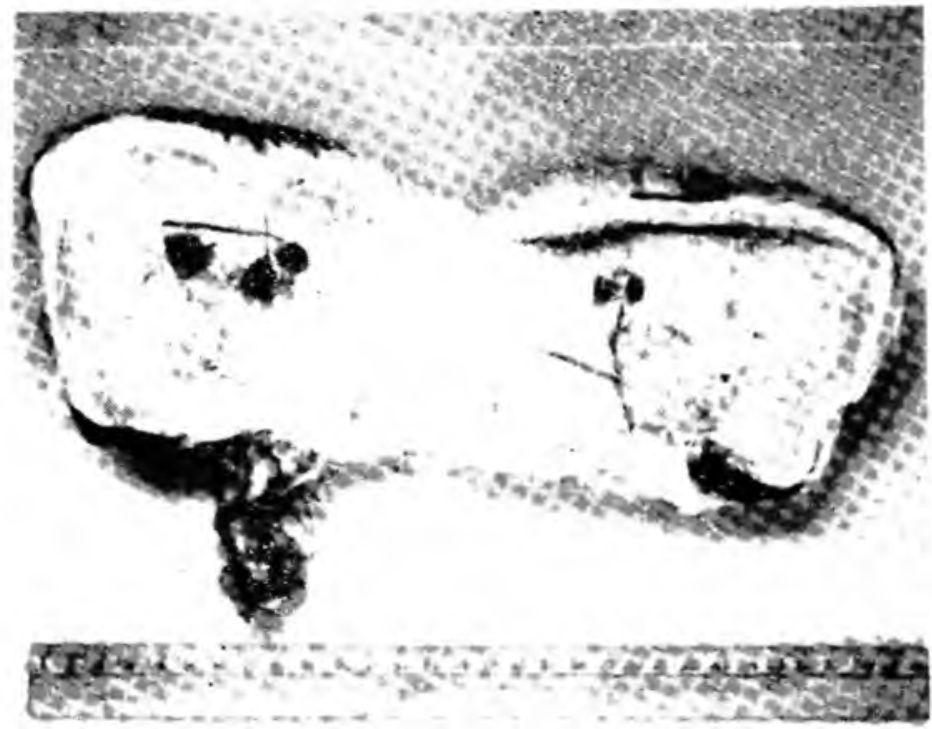

Caso 1 - Sminerfical da corte 

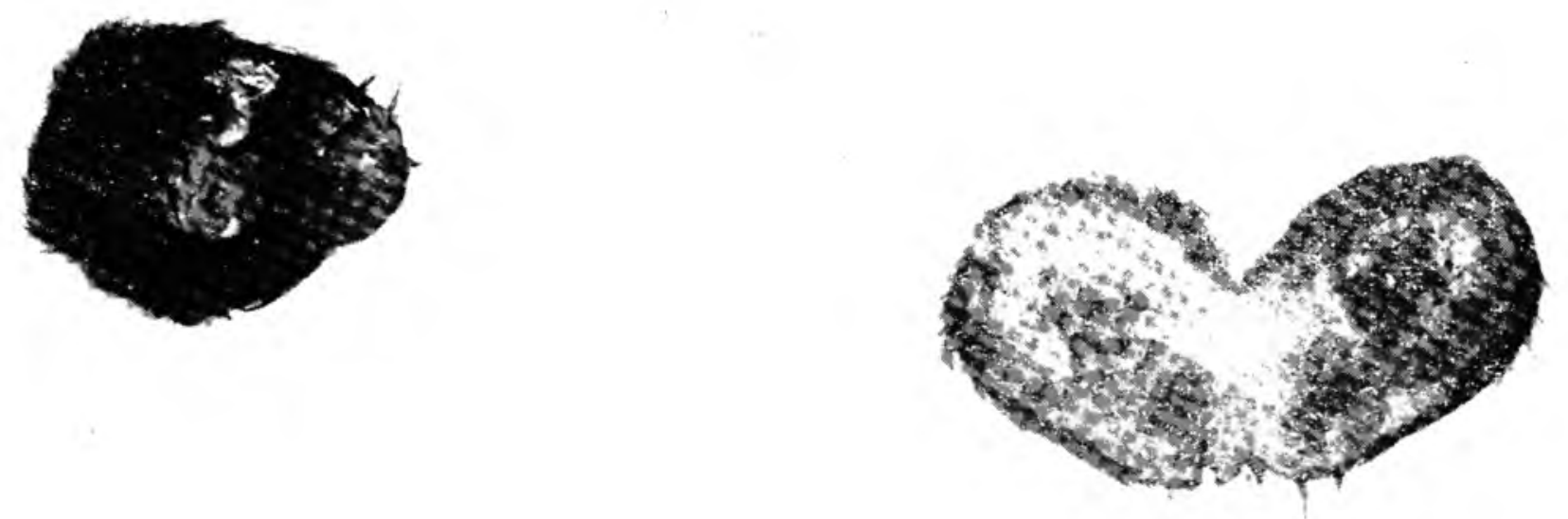

Casu 11 - Meinstero Anidlano

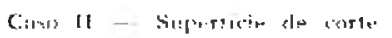

